\title{
強制外力を加えた一様磁場下の一様性MHD乱流の直接数值解析
}

\section{Direct Numerical Simulation for Homogeneous MHD Turbulence under External Force and Uniform Magnetic Field}

\author{
○正 岡本 正芳（静大院） \\ Masayoshi OKAMOTO, Shizuoka University, 3-5-1 Johoku, Naka-ku, Hamamatsu, 432-85611, Japan
}

Key Words: MHD, Turbulence, Direct Numerical Simulation, Uniform Magnetic Field, External Forces, Energy Transformation

\section{1. 緒言}

電離気体であるプラズマを連続体として取り扱う電磁流体 近似 (MHD) の支配方程式では速度場の非線形性に加え、さ らに磁場の非線形性も存在するため、乱流状態はより複雑 な物理現象となってくる。MHD乱流場が主な対象となる研 究分野は天体物理や核反応関連現象である。近年、MHD乱 流場においてその詳細なメカニズムを探求する目的から、 ハルトマン流れのような低磁気プラントル数MHD乱流だけ でなく、磁場の非線形性が強く作用する高磁気プラントル 数のMHDプラズマ場に関しても直接数值計算(DNS) を利用 した研究が行われるようになってきた。著者らの研究室で もMHD一様減衰乱流、強制一様等方性乱流や一様剪断乱流 において、初期エネルギーの分配、磁気プラントル数、初 期クロスヘリシティー、一様印加磁場、系回転などの効果 に関して探求してきた。MHD強制一様等方性乱流のDNSに よる結果からは低波数帯に速度場のみ線形関係となる外力 を導入したケースで定常状態を形成できることが確認され た。そこで、本研究ではその結果を利用し、一様磁場を印 加してどのようにMHD乱流が変化するかを検討していく。

\section{2. 基礎方程式と数値計算手法}

$x$ 方向に一様磁場 $B$ を印加した下での摇動速度 $u_{i}$ と摇動磁場 $b_{i}$ に関するMHD基礎方程式は以下である。

$$
\begin{array}{ll}
\frac{\partial u_{i}}{\partial t}+\frac{\partial u_{i} u_{j}}{\partial x_{j}}=-\frac{\partial p}{\partial x_{i}}+B \frac{\partial b_{i}}{\partial x}+\frac{\partial b_{i} b_{j}}{\partial x_{j}}+v \frac{\partial^{2} u_{i}}{\partial x_{j} \partial x_{j}}+f_{i}^{K} & \frac{\partial u_{j}}{\partial x_{j}}=0 \\
\frac{\partial b_{i}}{\partial t}+\frac{\partial b_{i} u_{j}}{\partial x_{j}}=B \frac{\partial u_{i}}{\partial x}+\frac{\partial u_{i} b_{j}}{\partial x_{j}}+\lambda \frac{\partial^{2} b_{i}}{\partial x_{j} \partial x_{j}} & \frac{\partial b_{j}}{\partial x_{j}}=0
\end{array}
$$

ここで、外力 $f_{i}^{K}$ は大きなスケール領域 $0<k<4$ において運動 および磁気エネルギーの総和である全エネルギーが一定に なるように導入した速度に平行な線形外力である。この MHD乱流場における支配パラメーターはレイノルズ数Re、 磁気プラントル数 $\operatorname{Pr}_{\mathrm{m}}=v / \lambda$ 、一様磁場強度 $B$ である。本研究 では $\mathrm{Pr}_{\mathrm{m}}$ を 1 とし、 Reは微分長に基づくレイノルズ数 $\mathrm{Re}_{\mathrm{T}}$ 、 $\mathrm{Re}_{\mathrm{TB}}$ を計算結果から算出する。印加磁場としては $B=0.5$ と 1 に設定している。計算の初期状態は磁場を印加しない場合 での速度に線形な外力を導入して得られたMHD一様等方性 乱流場の瞬間場データーとし、時刻 $t=0$ において急に磁場を 印加して、最終時刻 $t=20$ までのDNSを実行した。

本研究で計算に使用した方法としては、空間離散化には フーリエ変換をベースとする擬スペクトル法、時間発展に は拡散項に2次精度Crank-Nicolson法を、その他の項に2次精 度Adams-Bashforth法を採用した。エリアイジングエラーを 2/3ルールで除去したため有効解析モード波数は833であり、 対応する実空間格子系は $256^{3}$ である。

\section{3. 計算結果}

図1に摇動量の 2 体平均量である運動エネルギー $K$ 、磁気エ ネルギー $K_{B}$ 、クロスヘリシティーHの結果を与える。印加 磁場が加わった時刻 $t=0$ の直後に運動エネルギーは急速に減 少し、ほぼ磁気エネルギーと同レベルまで変化した後、再 びKが上昇し。 $K_{B}$ が減少している。計算最終時刻においても 定常とは言い難い状態となっている。印加磁場の大きさに よる違いは磁場印加直後の減少において $B=0.5$ の方が変化が 緩やかになっている点である。運動エネルギーが増加する 時間帯になると両ケースの差異は小さなものとなってお り、最終時刻における運動エネルギーと磁気エネルギーの
割合は印加磁場ゼロの場合よりも若干 $K$ が大きくなってい る。一方、クロスヘリシティーの時間変化は印加磁場がな い状態でほぼゼロであるのに対して、B=0.5のケースでは緩 やかに減少し -0.5 程度で時間的変化がなくなり、 $B=1$ では緩 やかに上昇して 0.15 程度でほぼ一定值となっている。時刻 $t=20$ でのレイノルズ数は $B=0.5$ では $\mathrm{Re}_{\mathrm{T}}=88.3, \mathrm{Re}_{\mathrm{TB}}=25.0$ であ り、 $B=1$ では $\mathrm{Re}_{\mathrm{T}}=88.2, \mathrm{Re}_{\mathrm{TB}}=21.2$ となった。これは印加磁場 ゼロのケースでのレイノルズ数 $\mathrm{Re}_{\mathrm{T}}=52.6, \mathrm{Re}_{\mathrm{TB}}=10.3$ に比べて やや大きな值を示す結果となつた。

運動エネルギーと磁気エネルギーの輸送方程式は

$$
\frac{\partial K}{\partial t}=P_{K}+\mathrm{M}+\Lambda-\varepsilon \quad \frac{\partial K_{B}}{\partial t}=-\mathrm{M}-\Lambda-\varepsilon_{B}
$$

となる。 $P_{K} 、 P_{B}$ は外力による生成項、 $\varepsilon_{、} 、 \varepsilon_{B}$ は散冕率、 $\mathrm{M}$ と ヘは平均磁場を介したエネルギー交換項と摇動磁場による エネルギー交換項であり、それらの定義式は以下で与えら れる。

$$
\begin{array}{lll}
P_{K}=\overline{f_{i}^{K} u_{i}} & \mathrm{M}=B \overline{u_{j} \frac{\partial b_{j}}{\partial x}} & \Lambda=b_{i} u_{j} \frac{\partial b_{j}}{\partial x_{i}} \\
\varepsilon=v \overline{\frac{\partial u_{i}}{\partial x_{j}} \frac{\partial u_{i}}{\partial x_{j}}} & \varepsilon_{B}=\lambda \overline{\frac{\partial b_{i}}{\partial x_{j}} \frac{\partial b_{i}}{\partial x_{j}}} &
\end{array}
$$

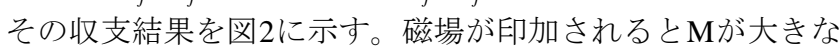
負值として運動エネルギーから磁気エネルギーへの変換が 行われ、時閒が経過寸るとその寄与はゼロ付近で摇らぐも のとなっている。同様に作用している負の $\Lambda$ に比べるとそ の交換としての働きは弱いものとなっている。散逸項に着 目すると磁気散逸率が運動散逸率よりも負で大きく、強く 消散させる効果を示している。

運動および磁気エネルギー散逸率の輸送方程式は

$$
\frac{\partial \varepsilon}{\partial t}=P_{\varepsilon}+\mathrm{M}_{\varepsilon}+\Lambda_{\varepsilon}+D_{\varepsilon} \quad \frac{\partial \varepsilon_{B}}{\partial t}=P_{\varepsilon B}-\frac{1}{\operatorname{Pr}_{m}} \mathrm{M}_{\varepsilon}-\frac{1}{\operatorname{Pr}_{m}} \Lambda_{\varepsilon}+D_{\varepsilon B}
$$

となる。 $P_{\varepsilon}$ と $P_{\varepsilon B}$ は生成項、 $D_{\varepsilon}$ と $D_{\varepsilon B}$ は散逸項、 $\mathrm{M}_{\varepsilon}$ は印加磁 場を介した散逸交換項で、 $\Lambda_{\varepsilon}$ は摇動場による散逸交換項で あり、

$$
\begin{aligned}
& P_{\varepsilon}=2 v \overline{\frac{\partial u_{i}}{\partial x_{j}} \frac{\partial f_{i}^{K}}{\partial x_{j}}}-2 v \overline{\frac{\partial u_{i}}{\partial x_{j}} \frac{\partial u_{i}}{\partial x_{m}} \frac{\partial u_{m}}{\partial x_{j}}}+2 v \overline{\frac{\partial u_{i}}{\partial x_{j}} \frac{\partial b_{i}}{\partial x_{m}} \frac{\partial b_{m}}{\partial x_{j}}}
\end{aligned}
$$

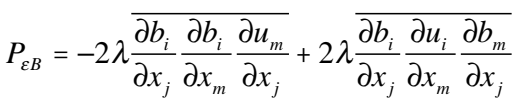

$$
\begin{aligned}
& \mathrm{M}_{\varepsilon}=2 v B \overline{\frac{\partial u_{i}}{\partial x_{j}} \frac{\partial^{2} b_{i}}{\partial x \partial x_{j}}} \quad \Lambda_{\varepsilon}=2 v b_{m} \frac{\partial u_{i}}{\partial x_{j}} \frac{\partial^{2} b_{i}}{\partial x_{m} \partial x_{j}} \\
& D_{\varepsilon}=-2 v^{2} \overline{\frac{\partial^{2} u_{i}}{\partial x_{j} \partial x_{m}} \frac{\partial^{2} u_{i}}{\partial x_{j} \partial x_{m}}} \quad D_{\varepsilon B}=-2 \lambda^{2} \frac{\partial^{2} b_{i}}{\partial x_{j} \partial x_{m}} \frac{\partial^{2} b_{i}}{\partial x_{j} \partial x_{m}}
\end{aligned}
$$

と定義される。図 3 は $\varepsilon$ の収支の結果である。磁場を印加し た直後に急激な变化を示すが、生成項と散冕項の印加磁場 の強度による差異は比較的小さなものである。しかし、交 換項に着目すると、 $B=0.5$ のケースでは両項ともほぼ同等な ゲインとして働いているが、 $B=1$ のケースでは摇動場に関す る交換項はロスとして、平均磁場を介した交換項は生成項 と同レベルの岙インとして作用している。

図4にレイノルズおよびマクスウェル応力の非等方成分 $b_{i i}$ の時間変化を与える。摇らぎは大きいが、時間が経過して くると、印加磁場方向であるレイノルズ応力の11成分は弱 
くなり、マクスウェル応力の11成分は大きくなる傾向が確 認できる。しかし、その值の大きさから非等方性としては かなり弱いものとなっている。

最終時刻での全エネルギースペクトル $E_{T}(k)$ とその中での 運動エネルギーの割合の結果を図5に示す。印加磁場の大き さの違いからくる差異は非常に小さく、磁場を印加しない ケースのー5/3乗に沿うスペクトルよりも急激なカスケード を示す結果となった。また、低波数帯の $k=3,4$ では特徵的な かなり大きな運動エネルギー保有を示すが、それ以上の高 波数領域では低い運動エネルギー保有となっている。最後 に時刻 $t=20$ での速度と磁場のパワースペクトルの非等方成 分 $B_{i i}(k)$ の結果を図6に示す。高波数領域での強印加磁場の $B=1$ の結果は速度のパワースペクトル 11 成分がかなり卓越し ている様子が確認できる。応力のような平均量とは異な り、一様磁場の印加により、小さなスケールでの非等方分 離は顕著なものとなっている。その他の詳細な結果は発表 時に譲る。

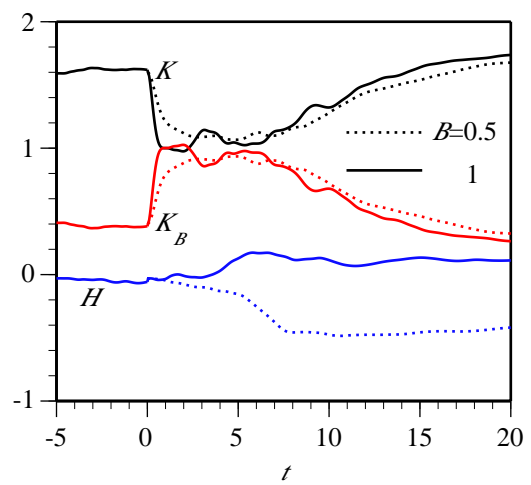

Figure 1 Kinetic and magnetic energy and cross helicity.
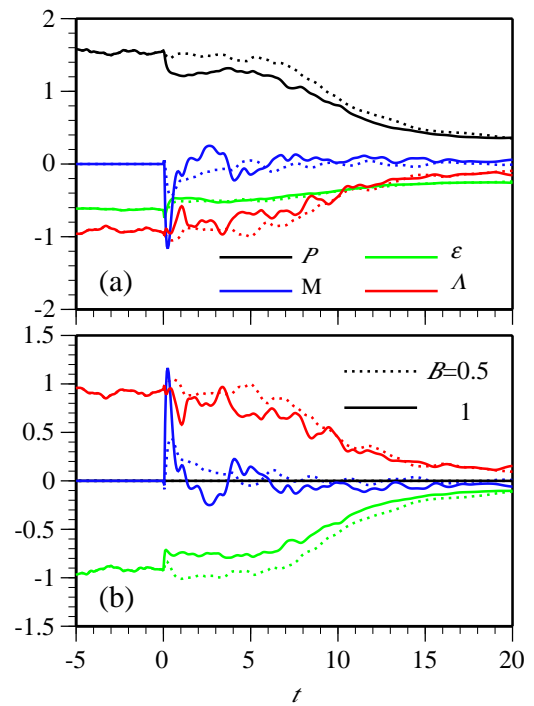

Figure 2 Kinetic and magnetic energy budgets. (a) $K$, (b) $K_{B}$.

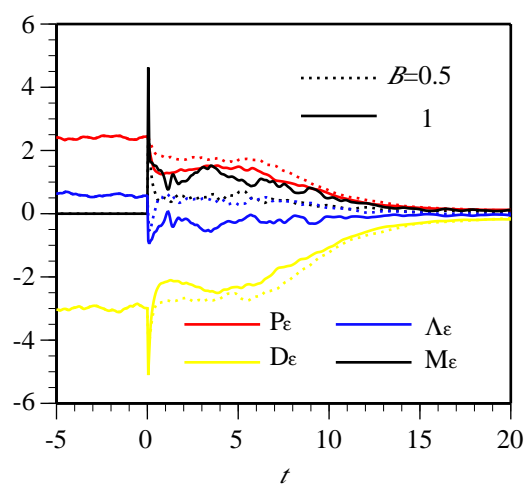

Figure 3 Kinetic dissipation budget.

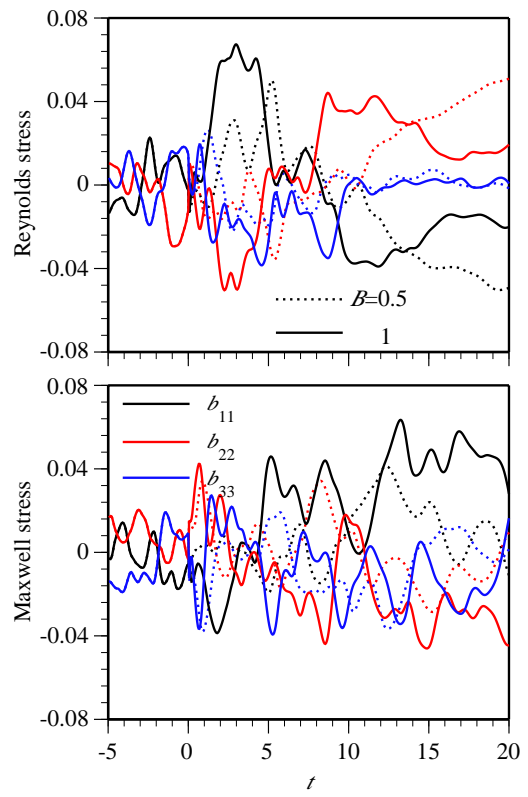

Figure 4 Anisotropic tensor elements of the Reynolds and Maxwell stress.

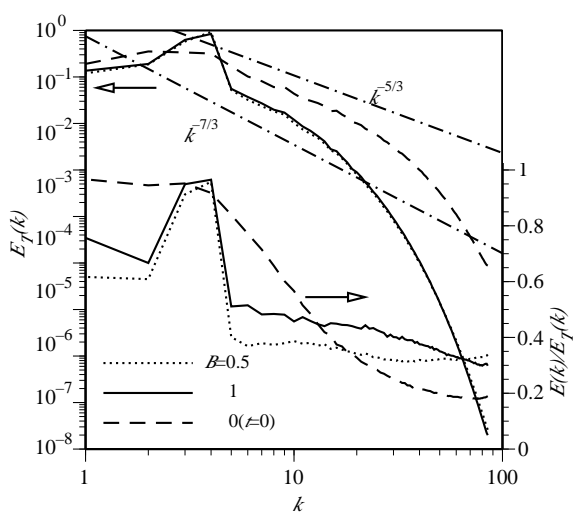

Figure 5 Total energy spectra $E_{T}(k)$ and ratio of the kinetic energy spectrum $E(k)$ to $E_{T}(k)$.

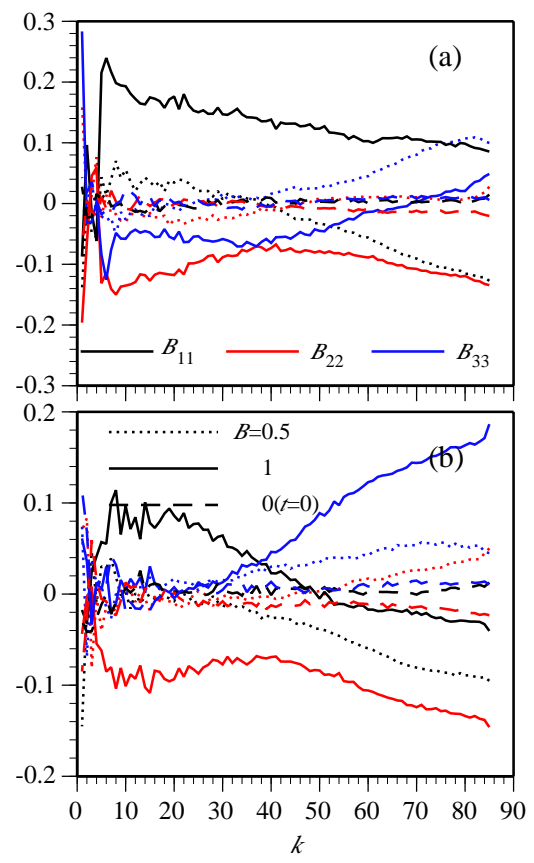

Figure 6 Anisotropy of the kinetic and magnetic power spectra at $t$ =20. (a) $B^{K}(k)$, (b) $B^{B}(k)$. 